\title{
Cultura pentecostal em periferias cariocas: grafites e agenciamentos políticos nacionais'
}

\author{
Pentecostal culture in Rio's peripheries: graffiti and national political agency
}

\section{Christina Vital da Cunhaa ${ }^{\circledR}$}

Resumo São inúmeras as investigações produzidas a partir dos anos 1990 cuja atenção recai sobre as mudanças identificadas no campo religioso brasileiro e suas repercussões em outras esferas da vida social. Neste artigo, retomo as formulações do memorável antropólogo Pierre Sanchis sobre "cultura popular urbana" com o objetivo de refletir, comparativamente, a respeito do crescimento pentecostal nas periferias a partir dos anos 2000. Este crescimento revelou composições entre referenciais culturais até então predominantes e novas formas de apropriação estética e gramatical com repercussões na sociabilidade, na economia e na política local e supralocal. Como base empírica das análises aqui propostas conto com entrevistas, dados e observações produzidos durante trabalho de campo realizado de modo intermitente em favelas cariocas, com ênfase na favela de Acari, além de dados de uma pesquisa realizada na Universidade Federal Fluminense mapeando templos religiosos na cidade do Rio de Janeiro

Palavras-chave Cultura Pentecostal. Periferias. Favelas. Evangélicos. Brasil.

Abstract There are countless investigations produced since the 199os, which focus on the changes identified in the Brazilian religious field and their repercussions in other spheres of social life. In this article, I return to the memorable anthropologist Pierre Sanchis' formulations on "urban popular culture" with the aim of comparatively reflecting on Pentecostal growth in the peripheries from the 20oos onwards. This growth revealed compositions between cultural references hitherto prevalent and new forms of aesthetic and grammatical appropriation with repercussions on sociability,

1 Agradeço a Luiz Antonio Machado (in memorian) pela leitura generosa e pelas sugestões feitas a esta versão enviada. Desde apresentações em 2006 e de publicações realizadas a partir de 2008 venho tratando da questão mais geral deste artigo (Religião em periferias - explorando as interfaces situadas com política, criminalidade violenta, sociabilidade e economia local). Em 2018 publiquei um artigo na Vibrant sobre "cultura pentecostal em periferias", fruto de uma apresentação no IESP em 2016 a convite de Palloma Menezes e Luiz Antonio Machado. Nesta versão, as questões centrais daquele artigo foram revistas e afinadas, assim como introduzidos dados de uma pesquisa realizada entre 2016-2017 na UFF sob minha co-coordenação.

a Professora do Programa de Pós-Graduação em Sociologia da Universidade Federal Fluminense (UFF), Rio de Janeiro, Brasil. Coordenadora do Laboratório de estudos em política, arte e religião - LePar e colaboradora do Instituto de Estudos da Religião - Iser. E-mail: chrisvital10@ gmail.com 
on the economy and on local and supralocal politics. As an empirical basis of the analyzes proposed here, I count on interviews, data and observations produced during intermittent fieldwork carried out in Rio's favelas, with an emphasis on the Acari favela, in addition to data from a survey conducted at Universidade Federal Fluminense mapping religious temples in the city from Rio de Janeiro.

Keywords Pentecostal culture. Peripheries. Shanty towns. Evangelicals. Brazil

Parece oportuno retomar as contribuições de Pierre Sanchis (1928-2018) para analisar as mais recentes transformações culturais existentes no Brasil urbano. ${ }^{2}$ No âmbito das ciências sociais da religião ${ }^{3}$, Sanchis foi um dos destacados autores a considerar o catolicismo como elemento-chave na conformação de uma "cultura nacional" estabelecendo marcadores de sociabilidade, assim como seus valores morais de referência. Em meio aos segmentos citadinos menos abastados, o catolicismo compunha o que Sanchis chamou de cultura popular urbana tradicional. Esta forma cultural era definida pelo autor por seu "pouco rigor moralista, pouca disciplina cívica, esforço laboral anárquico, apesar de muitas vezes intenso, e, do ponto de vista religioso, uma porosidade das identidades que permitia a cada um participar ao mesmo tempo de definições institucionais múltiplas” (Sanchis, 1997, p. 124). Com o crescimento da presença de evangélicos pentecostais no espaço público e de seus percentuais nos censos do IBGE desde, principalmente, a década de $1990^{4}$, a bibliografia especializada passou a refletir sobre as reações da Igreja Católica a este crescimento, assim como sobre o possível estabelecimento de uma "cultura pentecostal" no Brasil. Estes estudos ora destacavam processos de assimilação da cultura secular ${ }^{5}$ na nova forma cultural, ora exploravam-na como ruptura, como confrontadora de uma cultura e ordem vigentes.

Neste artigo pretendo me somar a um conjunto de estudos que apostam na potente confluência analítica entre religiões e cidades. Mais especificamente,

2 Algumas belas homenagens retomando a sua vasta obra foram feitas por ocasião de sua morte. Dentre elas destacaria as feitas por Regina Novaes (2018) e Carlos Steil (2018).

3 Contribuições importantes do mesmo período vieram de Oro (1988), Novaes (1997), Droogers (1987), entre outros.

4 Segundo dados do Instituto Brasileiro de Geografia e Estatística de 1991, os evangélicos correspondiam a 9\% do total da população. Dez anos depois, os dados do IBGE confirmaram a presença de 15,5\% de evangélicos no Brasil. Em 2010 esse percentual chegou a 22,2\%, o que corresponderia a 42,3 milhões de pessoas. Em 2016, o Instituto Datafolha aferiu o quantitativo de $29 \%$ da população como evangélica no Brasil.

5 Tomamos secular aqui não como um modo consolidado socialmente de oposição entre religioso e outras esferas da vida social (Weber, 1982; Eliade, 1992; Berger, 2004; Da Matta, 1991), mas como um modo de convivência do religioso nos âmbitos tomados como seculares compondo suas formas de apresentação e existência (ASAD, 1993; TAYLOR, 2010). Para uma reflexão sistemática sobre o tema ver Paula Montero (2006; 2012: 2016; 2018), Emerson Giumbelli (2002; 2008; 2013), Ricardo Mariano (2011; 2013), entre outros. 
pretendo analisar a conformação de uma cultura pentecostal em periferias considerando que o aumento no número de igrejas pentecostais e de seus fieis provocou mudanças em diferentes esferas da vida social nessas localidades, tais como na sociabilidade, economia, estética ${ }^{6}$, política, nas paisagens e na gramática ${ }^{7}$ articulada cotidianamente por seus moradores, sejam eles vinculados ou não à institucionalidade evangélica pentecostal. Nos limites destas páginas tratarei de apenas alguns aspectos destas mudanças, como a sociabilidade local e os agenciamentos políticos supralocais, já tendo apresentado, em outras produções, dados que subsidiavam as análises sobre outras interfaces deste fenômeno social (VITAL DA CunHa, 2015, 2019).

Em termos metodológicos talvez seja importante salientar que tratarei aqui de uma "cultura pentecostal em periferias" entre muitas aspas. Não só pela grande abstração que o termo "cultura" ativa, mas igualmente pela noção de "cultura pentecostal" tender a produzir uma percepção essencializada dos evangélicos sem destacar as diferenças que marcam a atuação e doutrina das diversas denominações em campo. No entanto, gostaria de defendê-la nesta proposta de trabalho, pois ela vem me parecendo especialmente eficaz para pensar sobre diferentes situações que marcam a vida social nestes territórios da cidade com reverberações na vida política supralocal.

Sendo assim, vale frisar, meu interesse recai menos sobre a vivência pentecostal institucionalizada, com atenção às normativas e teologias das igrejas, e mais sobre a difusão de imagens, estéticas, sobre os modos como as pessoas ativam, manipulam, operam referenciais morais do pentecostalismo na vida social em periferias formando uma base cultural permeável a narrativas produzidas e/ou difundidas por lideranças evangélicas, forjando, inclusive, aproximações entre mundos sociais até então não registrados na bibliografia, como, por exemplo, o

6 Lanço mão de uma noção de estética como conjunto de signos referido situacionalmente a noções de belo pelos atores envolvidos em sua produção e percepção, e que seriam, portanto, representações sociais envolvendo valores, crenças, expectativas. Neste ponto em especial, as imagens religiosas em Acari e nas outras favelas nas quais tive oportunidades distintas de pesquisa, conformam um conjunto de símbolos pictóricos que variam conforme o tempo e o conteúdo religioso em questão, mas que revelariam, assim, fé, expectativas de proteção, expressão de domínio, sociabilidades.

7 Por gramática tomamos a relação estabelecida socioculturalmente entre os termos usados por diferentes atore sociais em situação. A referência para este debate é a obra de Veena Das (2007) sobre a gramática de gênero e a violência a esta associada. A autora se indaga, entre outros, sobre de quê forma o gênero é acionado como uma gramática que autoriza a violência. Em sua perspectiva, os corpos são tomados como signos dessa gramática, expressivos dela. Em minha proposta analítica, não somente os corpos, mas as imagens (pinturas murais e grafites) são signos da gramática pentecostal ativada por moradores e pelos traficantes em favelas. 
mundo do crime. ${ }^{8}$ Minhas reflexões estão dirigidas, portanto, a uma modalidade difusa, não denominacional ${ }^{9}$, e que se revelou crescente no Brasil na última década.

Ao longo da etnografia realizada de modo intermitente entre os anos 1996 e 2015 na Favela de Acari, localizada entre bairros da Zona Norte da cidade do Rio de Janeiro, e, comparativamente, no Morro Santa Marta, Zona Sul do Rio ${ }^{10}$, entre 2005 e 2010, fiz entrevistas com moradores evangélicos e sem religião, com traficantes, com presidentes de associação de moradores, com líderes religiosos e missionários. ${ }^{11}$ Nestas oportunidades, e nas idas assistemáticas a campo posteriormente a este período de formação acadêmica, pude observar o comprometimento institucional de inúmeros moradores com as igrejas que frequentavam, assim como, por parte de outros atores, os usos difusos de um repertório que circulava entre evangélicos pentecostais.

Depois do período de decantação dessas experiências fundamentais, momento comum aos pesquisadores ao finalizarem seus trabalhos, o conjunto de situações experimentadas em campo me inspiraram e incentivaram a tentar dar forma analítica àquelas variadas presenças pentecostais nas favelas. Somado a tais experiências, também o contexto político mais geral e as pesquisas posteriormente realizadas sobre as modalidades de presença evangélica na mídia e na política foram importantes para a conformação deste interesse. Mais detidamente, além da etnografia de longa duração, as presentes análises se valem do material resultante da pesquisa "Mapeamento de Templos Religiosos no Rio de Janeiro - 2006 a 2016”, realizada em uma parceria entre a Universidade Federal Fluminense (UFF) e a Fundação Palmares (Brasília). ${ }^{12}$

8 Uma gama de estudos, a partir de meados dos anos 2000, passou a documentar estas aproximações entre mundos sociais distintos em termos políticos e de suas moralidades e convenções (Vital da Cunha, 2008; Teixeira, 2008, 2011; Feltran, 2011; Birman; Machado, 2012; Lopes, 2012; MACHADO, 2013b).

9 Os chamados desigrejados, segundo dados do censo do IBGE (2010), perfazem 2,9\% dos que se declaram evangélicos no Brasil. No entanto, esta modalidade de evangélicos que vivem sob o manto pentecostal a que me refiro seria composta por evangélicos integrados em denominações, os desigrejados e ainda pelos desviados - pessoas vinculadas a alguma igreja e que estão afastados do cotidiano de suas denominações de origem. Apresentam-se, no mais das vezes, como em situação transitória entre a igreja e o mundo, uma oposição moral muito marcante neste grupo religioso.

10 Valendo-me, para a análise, de experiências de campo em favelas como Cantagalo e Pavão-Pavãozinho por ocasião de pesquisa realizada entre 2010 e 2014 no âmbito do CEVIS, grupo de estudos coordenado por Luiz Antonio Machado da Silva e Márcia Leite.

11 Este material está disponível de modo mais extenso em Vital da Cunha (2015).

12 Esta pesquisa integrava o projeto de extensão denominado "Promoção e Defesa da Liberdade Religiosa", vinculado à Pró-Reitoria de Extensão da Universidade Federal Fluminense, sob minha coordenação e do professor André Brandão. 


\section{PENTECOSTALISMO EM MOLDES E NÚMEROS}

A chegada (1910) e difusão do pentecostalismo no Brasil parecia conformar "um desafio direto ao Brasil tradicional" (SAnchis, 1997, p. 124). O "jeitinho brasileiro" que adapta normas e sugere comportamentos que equilibram a lei e o costume estaria chegando ao fim com a modernidade que se impunha com esse novo cristianismo (Mafra; PAUla, 2002). Nessa perspectiva, o pentecostalismo representaria uma ruptura cultural e ética com os moldes sobre os quais se assentariam a sociedade brasileira e com as tradições religiosas vigentes. A percepção social do pentecostalismo como religião de ruptura, exclusivista, ascética, "solvente" de vínculos sociais e heranças culturais (PIERUCCI, 2006) ainda é corrente no Brasil, embora inúmeras composições e continuidades culturais sejam identificadas. Assim, o que a bibliografia especializada passou refletir foi sobre o "abrasileiramento" do pentecostalismo. Pierre Sanchis (1998) sugere que entre a pentecostalização da cultura brasileira e o abrasileiramento do pentecostalismo, a Universal é a prova cabal de que foi o segundo movimento aquele bem-sucedido. Inúmeros outros estudos somaram-se ao diagnóstico: estabeleceu-se então que a ruptura do pentecostalismo com os parâmetros do nacional era apenas parcial" (Mafra; Paula, 2002, p. 61). Nesse mesmo sentido, Joel Robbins (2004) atribui o sucesso do pentecostalismo global a sua capacidade de adaptação "a partir de seus próprios termos". Seu crescimento seria fruto dessas adaptações, ao mesmo tempo em que de seu caráter moderno, ocidental e identificado com o neoliberalismo.

A adaptação cultural "a partir de seus próprios termos", tal como assinala Robbins (2004), foi observada por Sanchis nos rituais do pentecostalismo a partir dos anos 1990: "O culto pentecostal, marcadamente musical, emocional, feito de explosões individuais coletivamente reguladas, encontrava o seu lugar, específico mas plausível, entre as 'festas' que desde sempre marcavam o cotidiano religioso do brasileiro popular" Sanchis, 1997.).

\section{NÚMEROS DE EVANGÉLICOS NAS PERIFERIAS}

Nos anos 1990 os evangélicos conformavam um segmento religioso crescente em termos de sua presença em diferentes esferas da vida social brasileira - na mídia, na política, na economia, na cultura. O percentual dos que se declaravam evangélicos no Brasil em 1980 era de 6,6\%, segundo dados do IBGE. Em 1990 eram $9 \%$ da população nacional ${ }^{13}$, enquanto os católicos somavam $83,8 \%$. Embora

13 Dados do Censo Institucional Evangélico (CIN), de 1992, já mostravam a concentração do número de templos e fieis em periferias do Rio de Janeiro como bairros da Zona Oeste, Baixada Fluminense e Região Metropolitana. 
numerosos e bastante atuantes publicamente desde a década de 1970, pouco se sabia sobre eles, fortalecendo um sentimento geral de que eram os outros em relação ao nós católico ${ }^{14}$.

Nos anos 2000 os evangélicos já somavam 15,5\%, enquanto os católicos caíram para 73,8\% da população nacional. Com base nos microdados do IBGE, Jacob et al (2004) produziram mapas religiosos da cidade e região metropolitana identificando a incidência de religiões por área. Assim, verificaram que o catolicismo era mais presente ao longo da faixa litorânea "que se estende do Recreio dos Bandeirantes ao Centro da cidade, passando pela Barra da Tijuca, São Conrado, Leblon, Ipanema, Copacabana, Leme, Botafogo, Flamengo. A esta faixa se acrescentam Gávea, Jardim Botânico” (ЈАСов et al, 2004, p. 136). Nesta faixa, os católicos representavam quase 80\% da população. Inversamente, na maioria dos municípios da periferia, a religião católica representava menos de “48\% dos seus habitantes. As porcentagens de católicos são ainda mais reduzidas em áreas de Nova Iguaçu, Belford Roxo e São Gonçalo, entre 41\% e 30\%” (JACOB et al, 2004, p. 136).

Na pesquisa "Mapeamento de Templos Religiosos no Rio De Janeiro 20062016" (PROEX/UFF), verificamos o surgimento de 4.031 locais de culto religioso na cidade no intervalo de 10 anos, o que representa mais de um local criado por dia no período. Seguindo a tendência que César Jacob apontava georreferenciando a religião dos habitantes da cidade, a pesquisa de mapeamento UFF identificou que as denominações evangélicas criaram nas áreas periféricas e de menor renda per capta a maior parte de seus templos no período estudado. Na Zona Sul, Zona Oeste 1 (Barra da Tijuca e Recreio dos Bandeirantes) e Central foram registrados o menor percentual de templos no total (2,93\%, 2,16\% e 2,65\% respectivamente). As Zona Oeste 2 (Bangu, Realengo, Deodoro, Paciência, Padre Miguel, entre outros) e Zona Norte foram aquelas nas quais mais foram registrados novos templos nos últimos 10 anos, conforme vemos na tabela abaixo. Vale lembrar que na Zona Oeste 2 o maior número de templos criados foi de denominações evangélicas e na Zona Norte, católicos e de religiões afro-brasileiras.

14 A publicação do livro Novos Nascimentos: os evangélicos na casa, na rua e na política (1998) foi um marco nos estudos sócio antropológicos sobre evangélicos no Brasil naquele período. 
Tabela 1. Percentual de Templos Abertos por Áreas da Cidade entre 2006 e 2016.

\begin{tabular}{|c|c|}
\hline Área da cidade & $\begin{array}{c}\text { Percentual de templos/locais de culto } \\
\text { registrados no período }\end{array}$ \\
\hline Zona Oeste 2 & $53,11 \%$ \\
\hline Zona Norte & $38,30 \%$ \\
\hline
\end{tabular}

Fonte: Pesquisa Mapeamento de Templos no Rio de Janeiro, 2017.

Do total de templos abertos na cidade entre 2006 e 2010, cerca de $13 \%$ estão localizados em favelas. Somente religiões de matriz afro-brasileira e denominações evangélicas criaram espaços de culto nestas áreas nos últimos anos, conforme vemos na tabela abaixo.

Tabela 2. Percentual de Templos Abertos em Favelas entre 2006 e 2016.

\begin{tabular}{c|c} 
Afro & Evangélicos \\
\hline $3 \%$ & $15 \%$ \\
\hline
\end{tabular}

Fonte: Pesquisa Mapeamento de Templos no Rio de Janeiro, 2017.

Entre os três grandes grupos religiosos no Brasil, em acordo com a classificação do IBGE, as denominações evangélicas foram as que mais registraram templos nos últimos anos, conforme vemos na tabela abaixo (Tabela 3). Somente a igreja pentecostal Assembleia de Deus foi responsável pelo registro de $45 \%$ dos templos evangélicos no Rio de Janeiro no período de dez anos.

Tabela 3. Percentual de Templos Abertos por Religião entre 2006 e 2016.

\begin{tabular}{l|c|c}
\multicolumn{1}{c|}{ Religião } & $\begin{array}{c}\text { Número de templos/locais de culto } \\
\text { registrados }\end{array}$ & Número Percentual no período \\
\hline Evangélica & 3550 & $88,07 \%$ \\
\hline Católica & 232 & $5,76 \%$ \\
\hline Afro-brasileira & 88 & $2,1 \%$ \\
\hline
\end{tabular}

Fonte: Pesquisa Mapeamento de Templos no Rio de Janeiro, 2017.

Em 2010, segundo dados do IBGE, os evangélicos perfaziam 22,2\% da população nacional. Os católicos apresentavam queda de quase 10\% em relação ao censo anterior correspondendo, então, a 64,6\% dos brasileiros. Embora o crescimento de pentecostais nas camadas médias e altas da sociedade seja um dado empírico relevante, os dados do IBGE atestam que o aumento de evangélicos no Brasil desde 1970 é mais significativo em meio urbano e, sobretudo, em suas periferias geográficas e sociais. Em termos quantitativos isso significava que $87 \%$ dos que se declaravam evangélicos no Brasil em 2000 viviam no meio urbano. Em 2010 este percentual subiu para $89,47 \%$, segundo dados do IBGE. 
Etnografias diversas acompanharam este crescimento do pentecostalismo em favelas e periferias analisando seus impactos ${ }^{15}$. Na sessão seguinte, me somando aos estudos realizados, enfocarei dados coletados a partir do trabalho de campo na favela de Acari como meio de analisar mudanças mais recentes identificadas no tocante aos modos de expressão e organização local da população, inclusive de traficantes. Se até aqui a referência a estatísticas e uma breve revisão da bibliografia sobre pentecostalismo no Brasil foram enfatizados, abaixo a "leitura de imagens" será amplamente utilizada como recurso metodológico. Meu objetivo, com isto, será "vasculhar usos de imagens não como ilustrações, mas como documentos que, assim como os demais, constroem modelos e concepções" (SchwARCZ, 2004, p. 393).

Considero, portanto, que as imagens (no caso específico, os grafites e pinturas murais em favelas) exercem algum tipo de agência ganhando neste trabalho um papel central. Sendo assim, elas atualizam e rememoram sentimentos religiosos, nos termos propostos por Latour (2004). Mais do que expressar uma mensagem racionalmente capturada, as imagens produzem sentimentos no receptor. $\mathrm{O}$ exercício de descongelar as imagens, ou seja, de acompanhar o fluxo de imagens produzidas, ainda segundo Latour, é condição sine qua non para compreensão dos processos de transformação mútua (de emissores e receptores) sobre os quais pretendo refletir. A busca por visibilidade, aspecto importante na conformação da "cultura pública evangélica", segundo Giumbelli (2013), ganha destaque em minha análise sobre o contexto das periferias com vistas a refletir, ainda, sobre agenciamentos políticos contemporâneos no Brasil.

Minha ambição aqui é analisar transformações, percepções e estratégias de emissores em situação. Se, como vimos anteriormente, a bibliografia trata de enfatizar a importância do corpo e da música nos rituais e na experiência religiosa evangélica de um modo mais geral, destacarei as imagens produzidas tratando-as como códigos de uma comunidade - ainda que imaginada, nos termos de Anderson (2008) -, de uma identidade, portanto, pentecostal.

Nos limites deste texto, não será possível fazer uma revisão do conceito de identidade. Contudo, parece importante dizer que não a trato como uma espécie de emanação "do modo de ser de um grupo particular, tampouco o resultado imediato de suas condições de vida” (MonTero, 2012). Identidades são construídas discursivamente e dependem de um processo de mediação social no qual participam diferentes agentes humanos e não humanos. Identidade seria, portanto, resultado

15 Um trabalho muito inspirador desde o início desta jornada de pesquisa foi o de Clara Mafra (1998). 
de configurações (disputas e acordos) sempre situacionalmente definidas em um espaço/tempo. Assim, falar de identidade é falar em diferenças. Estas, assumindo um lugar absolutamente fundamental nas relações sociais, na medida em que "a diferença perante outros indivíduos é muito mais importante que a semelhança entre eles" (Simmel, 2006 [1908], p. 46). Como também nos lembra Poutignat e Streiff-Fernart (1998), o conceito remete a uma gama de possibilidades de identificação que denunciam a sua vitalidade e possibilidades analíticas, sendo vista por Lévi-Strauss como uma "ilusão totêmica", conforme Rocha (2014) ao tratar das roupas rituais em festas populares. Ainda assim, e cada vez mais, observamos como a ativação de uma identidade religiosa produz força interna (MARIANO, 2016; BIRMAN, 2012) que pode se reverter em diferentes capitais sociais. Neste sentido, a noção de identidade social virtual, de Goffman (1980), é válida na medida em que ela se refere a expectativas em relação aos indivíduos em situação de interação.

\section{TRÊS DÉCADAS DE PINTURAS EM ACARI}

As pinturas realizadas nas décadas de 1990 e 2000 por moradores e/ou por artistas contratados por traficantes na favela de Acari foram analisadas em trabalhos anteriores (Alvito, 2001; VitAl DA CunHA, 2014, 2015) como forma de acessar dinâmicas sociais em curso naquela localidade e que espelhavam mudanças presentes em outros espaços da cidade. Na década de 1990, por exemplo, os símbolos religiosos mais frequentes em imagens e pinturas dispostas em espaços comuns na favela de Acari eram São Cosme e Damião, São Jorge, São Jerônimo e Nossa Senhora Aparecida. Eram comuns ainda as imagens de Zé Pelintra em altares ou casinhas de santo construídas de cimento e revestidas de azulejos em esquinas nas favelas. Em várias pinturas, os símbolos católicos emergiam com referência aos correlatos na umbanda ou candomblé. Assim, encontrávamos Salve Doum, Xangô, Ogum ao lado das pinturas dos santos. ${ }^{16}$

16 Para saber mais sobre as festividades envolvendo São Cosme e Damião ver Menezes (2016) e Gomes (2009). Para ver de modo resumido considerações sobre todas as entidades, orixás e santos presentes nas imagens registradas nas favelas durante a pesquisa acessar Alvito (2001) e Vital da Cunha (2015). 




Imagem 1. Momento 1- Estética medieval. Imagem de São Jorge sobre o dragão. Sem identificação de autoria. Favela de Acari. Foto: Marcos Alvito. Ano 1996.

$\mathrm{Na}$ época, os terreiros locais tinham atividades rotineiras abertas aos moradores de Acari e filhos de santo residentes em outras partes da cidade. Traficantes locais também frequentavam o terreiro, consultavam búzios, pediam proteção aos orixás, faziam oferendas, contribuíam com festas de santos. Nos dias de São Jorge e de São Cosme e Damião, principalmente, havia salva de fogos, festa e, no segundo caso, distribuição de doces e brinquedos para as crianças locais.

Inspirada na discussão de Mauss (2003 [1902]) sobre a magia, Maggie sublinha que ela tem como característica ser oculta, "se esconder do coletivo e do público, reservando-se a espaços mais individuais e privados” (MAGGIE, 1992, p. 21). No entanto, continua a autora, a magia "transborda os limites espaciais da casa onde se realizam os rituais e insiste em aparecer em locais públicos de forma misteriosa, às escondidas - nos despachos, oferendas, ebós, feitiços" (MAGGIE, 1992, p. 21). Em Acari, a magia, as crenças de moradores e traficantes transbordavam os limites de casas e terreiros não de forma misteriosa, mas ostensiva ocupando ruas com seus ícones sagrados, suas cantorias e preces.

Nos anos 1990 já se percebia o crescimento no número de evangélicos em Acari. Este crescimento se expressava na formação de uma paisagem evangélica composta por templos, faixas e cartazes anunciando cultos, campanhas, testemunhos, louvores, celebrações, pela formação de uma paisagem sonora, nos termos tratados por Oosterbaan (2008), comércios gospel, pelos trajes mais austeros de mulheres e homens em relação ao modo de se vestir de outros moradores não evangélicos do local. Foi precisamente ao final desta década que a conversão de um traficante, líder do então Terceiro Comando, transforma os murais da favela, 
revelando, e ao mesmo tempo interferindo, assim, no prestígio relativo que evangélicos e religiosos de matriz afro-brasileira tinham na localidade.

Nos anos 2000, os evangélicos ocupam de vez a paisagem da favela. O crescimento no número de templos foi da ordem de quase $50 \%$ enquanto os terreiros deixaram de realizar atividades públicas (VITAL DA CunHA, 2015). As pinturas de santos, de ícones da música e referências étnicas, assim como símbolos futebolísticos, foram dando, gradativamente, lugar a passagens bíblicas. Partindo para a leitura dessas imagens, percebemos suas agências e as combinações de sentidos entre texto e a forma estética utilizada. Sendo assim, as imagens (texto e forma) remetiam ao Antigo Testamento, ao Deus da Guerra, ao Deus de Davi.

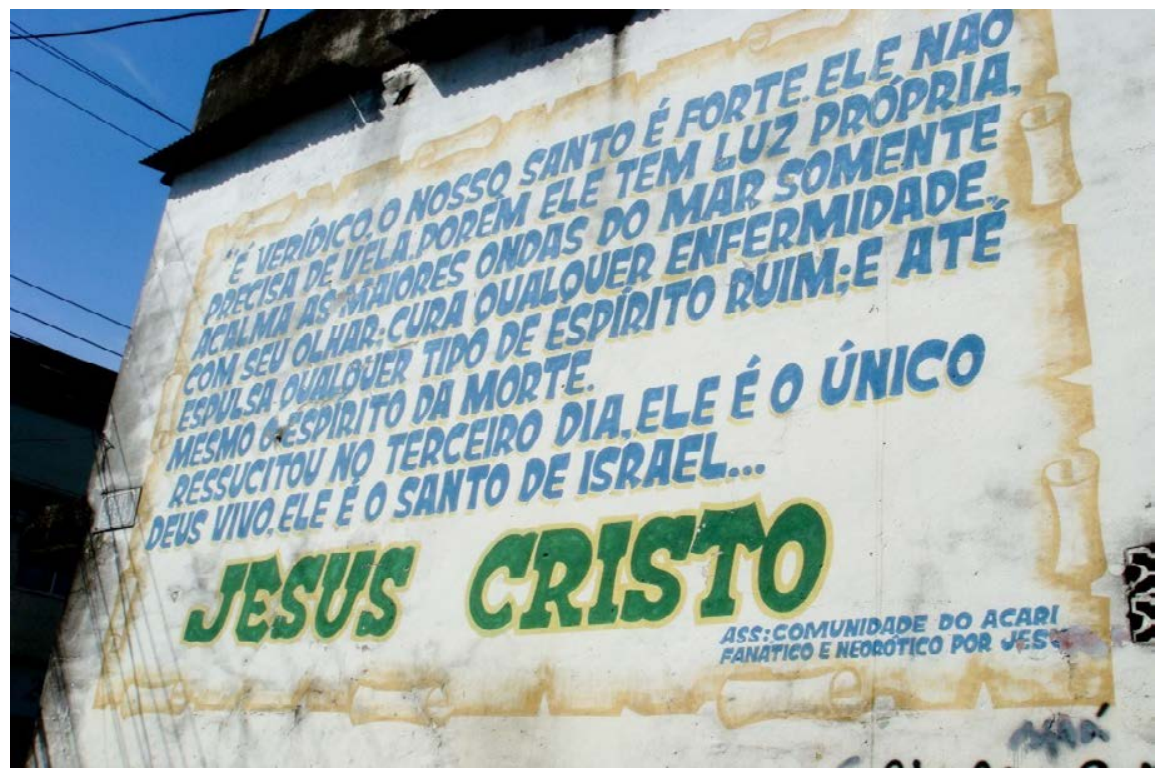

Imagem 2. Referências religiosas textuais com a assinatura de um coletivo. Universo Evangélico da Batalha Espiritual. Favela de Acari. Foto: Christina Vital. Ano 2008.

Neste período, o então mais procurado chefe do tráfico do Terceiro Comando, nascido e criado em Acari, converteu-se à igreja Assembleia de Deus dos Últimos Dias. A partir de sua conversão e de seu retorno do curto período passado na prisão, agora como chefe do tráfico e ao mesmo tempo evangélico, uma série de mudanças ocorreram na gestão do comércio de drogas em sintonia com mudanças nas esferas política e econômica locais. Uma atualização de antigas dinâmicas do crime ocorreu a partir de justificativas religiosas. O processo de destruição de imagens católicas e afro-brasileiras, inicialmente realizada pelos policiais civis que ocuparam a favela em meados da década de 1990 (Alvito, 2001), seguiu seu curso e contava agora com o incentivo dos próprios traficantes que financiavam artistas locais para fazerem murais com textos bíblicos. 
Conforme foi possível identificar, através da observação de imagens, do crescimento no número de templos evangélicos e de entrevistas com moradores, seguindo as pistas de Anderson (2008) ${ }^{17}$, as pinturas em Acari davam visibilidade a identidade marcada por uma forma religiosa predominante naquele momento. Segundo o autor, a eficiência desses símbolos se daria no interior de uma lógica comunitária específica na qual, a despeito dos conflitos sempre presentes no cotidiano de qualquer grupo social, a identidade e coletividade anunciadas pareciam "essenciais, naturais" porque partilhadas. No contexto específico, as imagens, em diferentes momentos, em razão de relações hierárquicas situacionalmente estabelecidas, reforçavam uma relação intrínseca entre aquela coletividade e os universos religiosos ora católico, afro-brasileiro, ora pentecostal. As imagens eram, portanto, agentes naquele contexto.

Acompanhar as imagens em movimento foi uma estratégia metodológica não planejada desde o início, mas que possibilitou produzir chaves de análise para cada momento. Assim, nos anos 2010, mais precisamente em 2013, as imagens em Acari já eram outras. Ainda evangélicas, mas com outra estética. As pinturas com trechos do Antigo Testamento foram substituídas por novas mensagens. As mudanças entre a estética anterior e a que se apresentava agora na favela eram muitas. Além do amplo uso do Novo Testamento, era possível identificar um conjunto de palavras que juntas formavam uma paisagem motivacional composta por textos, palavras e cores referidas à alegria, ao bem viver, de incentivo à fé, à paz e ao amor. A forma das letras passa a ser arredondada, não mais fonte Old English ou outras identificadas em papiros ou pergaminhos de manuscritos sagrados antigos. A identidade jovem das novas mensagens emergia pela estética referida ao grafite, mas também pelo uso de personagens de histórias em quadrinho, como podemos ver a seguir:

17 Ao tratar da formação de comunidades imaginárias nacionais, adaptado aqui para refletir sobre o caso da favela de Acari. 


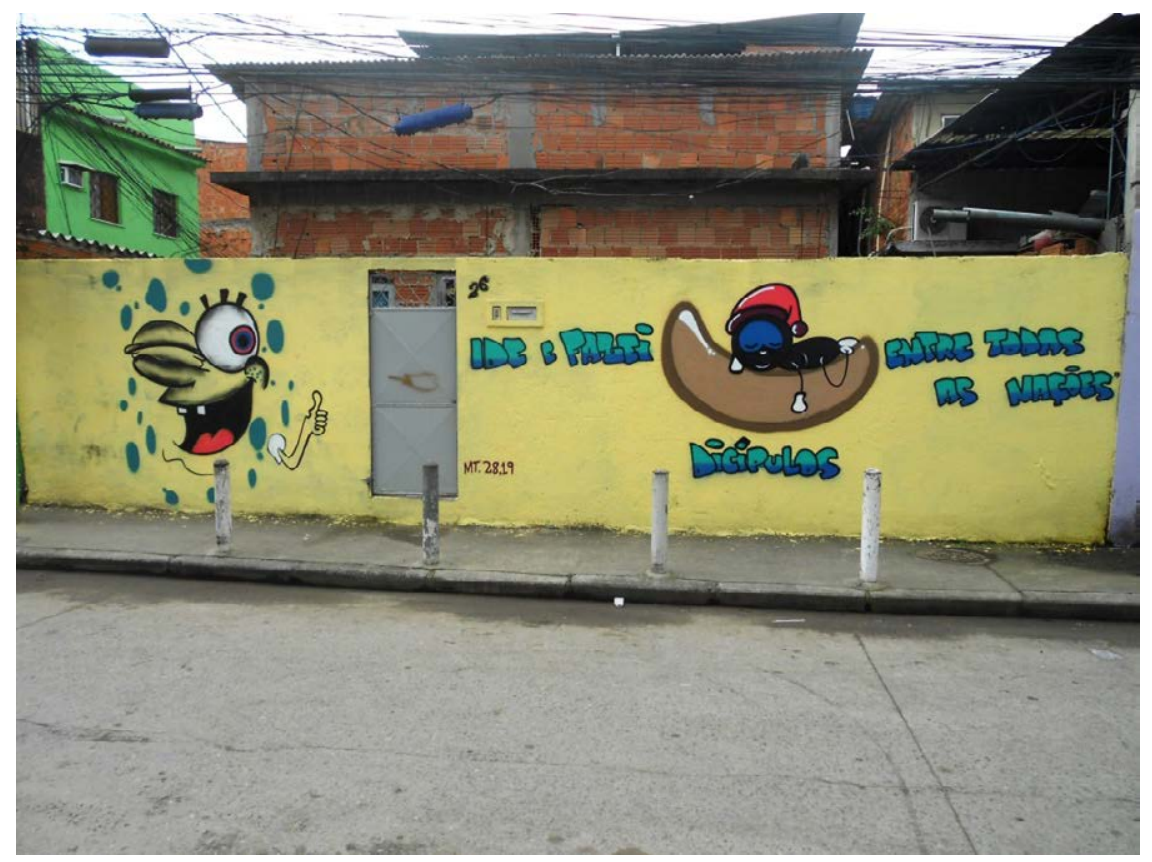

Imagem 3. Grafite Evangélico - MT. 28:19. Personagem Smiligüido. Favela de Acari. Foto: Christina Vital. Ano 2013

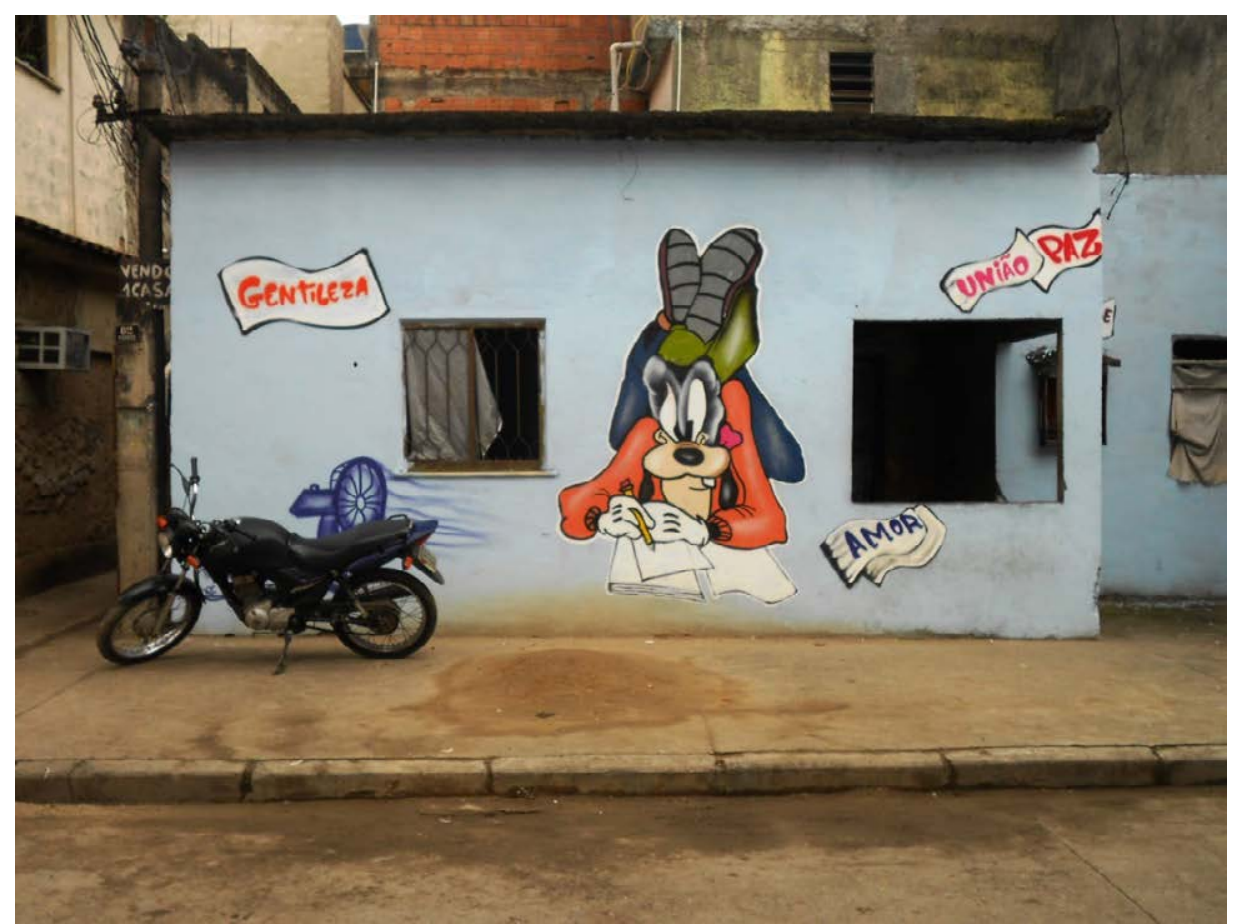

Imagem 4. Grafite Evangélico Motivacional. Favela de Acari.Foto: Christina Vital. Ano 2013

As pinturas passam a ter uma assinatura: são identificadas com um coletivo de artistas (Os grafiteiros de Jesus) e, algumas delas, com um artista em especial (André Soldado). A nova estética me chamou atenção, o grafite do tipo hall of 
fame. As mudanças nas imagens, a mensagem religiosa motivacional, doce, como dizia Gilberto Freyre sobre o cristianismo no Brasil, correspondiam, ao mesmo tempo, a mudanças no modo de evangelização e atuação da juventude evangélica, quanto a outra dinâmica de traficantes locais. Segundo um dos artistas da crew responsável por grafitar Acari em 2013, em entrevista realizada por mim em abril de 2017, as pinturas foram financiadas pelos traficantes da favela, o projeto artístico foi idealizado e oferecido a eles por um jovem evangélico, frequentador da Assembleia de Deus dos Últimos Dias. O compromisso era pintar todos os muros da favela por uma remuneração semanal distribuída por este intermediário aos grafiteiros. O estilo e os textos eram selecionados pelo idealizador do projeto tendo em vista a produção de uma paisagem mais "agradável, animada" como disse o grafiteiro entrevistado.

A destruição das imagens pregressas, como salientou Taussig (2009) e também Musil (2006) e Sansi (2005), lança sobre elas uma surpreendente visibilidade, descongelando-as, tirando-as da invisibilidade a que foram fadadas pela ostensividade de suas presenças no espaço. ${ }^{18}$ Sendo assim, os grafites religiosos de 2013 emergiam chamando atenção para o passado e para o presente. Significavam, ainda, um marcador do novo momento na gestão do tráfico. Mais especificamente, as imagens anteriores, em sua maioria produzidas por solicitação do chefe do tráfico à época, expressavam o momento de uma vinculação à narrativa religiosa da "batalha espiritual" pela via de sua integração à Igreja Pentecostal Assembleia de Deus dos Últimos Dias e o prestígio político do qual esta denominação gozava entre os traficantes e parte dos moradores. Posteriormente ao seu afastamento desta igreja e de seus esforços na criação de uma denominação independente com sede em Brasília, as pinturas mudaram. A nova chefia do tráfico local, aceitando o projeto de um evangélico que intermediou sua relação com os profissionais responsáveis pelas novas pinturas, expressava outro tempo na administração do crime e nas relações com líderes religiosos.

Em 2015 quem estava na chefia do comércio de drogas local era um traficante jovem e umbandista, mas o financiamento para ampliação dos murais com mensagens bíblicas continuou. No portão da quadra (anteriormente conhecida como "quadra de areia") há um enorme grafite referindo-se a Jesus. Na década de 1990 ali havia uma pintura de Bob Marley sobre uma folha de maconha. Na

18 Sobre os processos de descongelamento de imagens ver Latour (2004). Para uma interessante discussão sobre os usos da noção de invisibilidade ativa ver Giumbelli (2010). 
década seguinte havia um texto bíblico em formato de pergaminho. Em $2013 \mathrm{e}$ 2015 novas pinturas com referências cristãs emergiram.

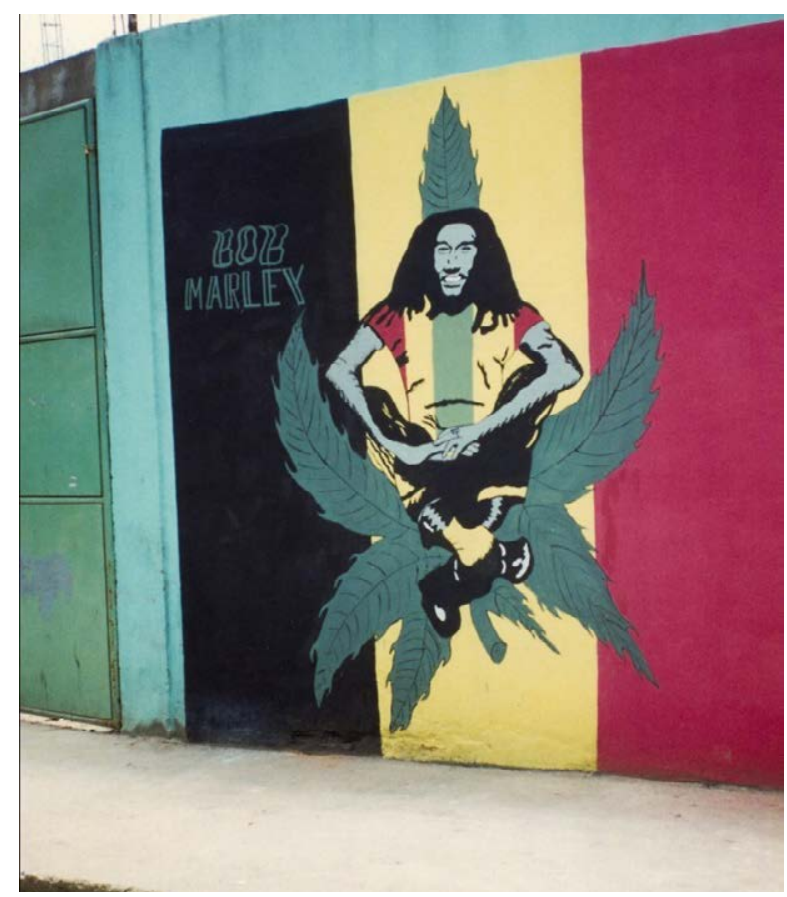

Imagem 5. Muro à direita do Portão da Quadra de Areia. Foto: Marcos Alvito. Ano 1996.

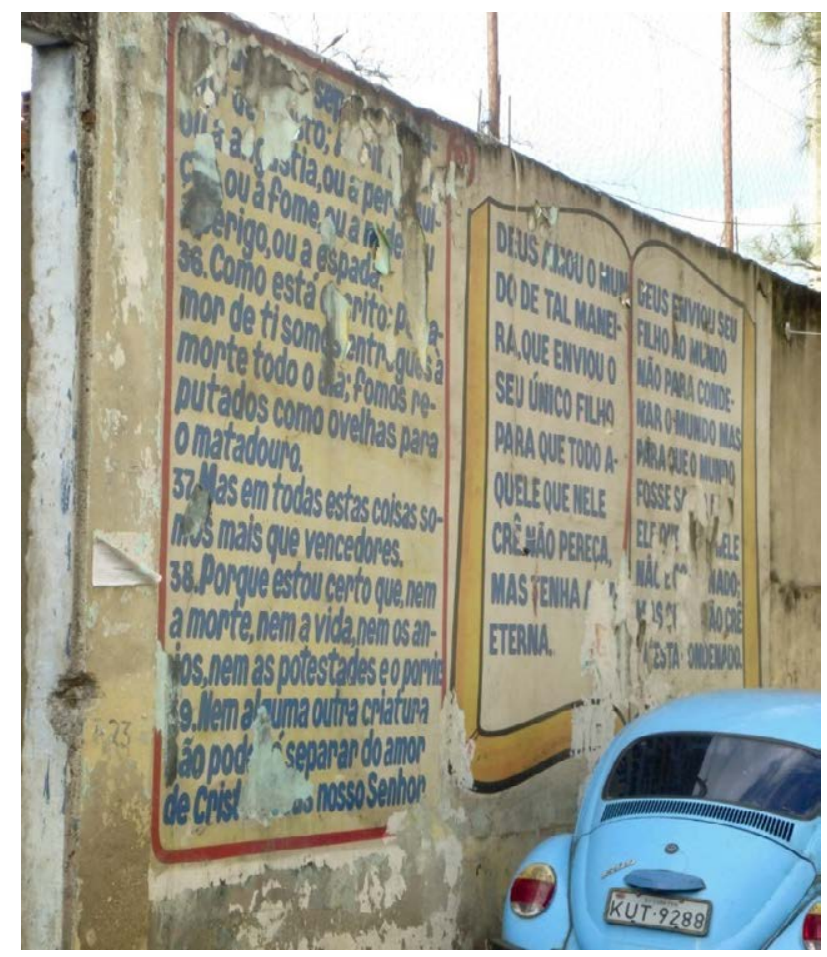

Imagem 6. Muro à direita do Portão da Quadra de Areia. Foto: Christina Vital. Ano 2006. 


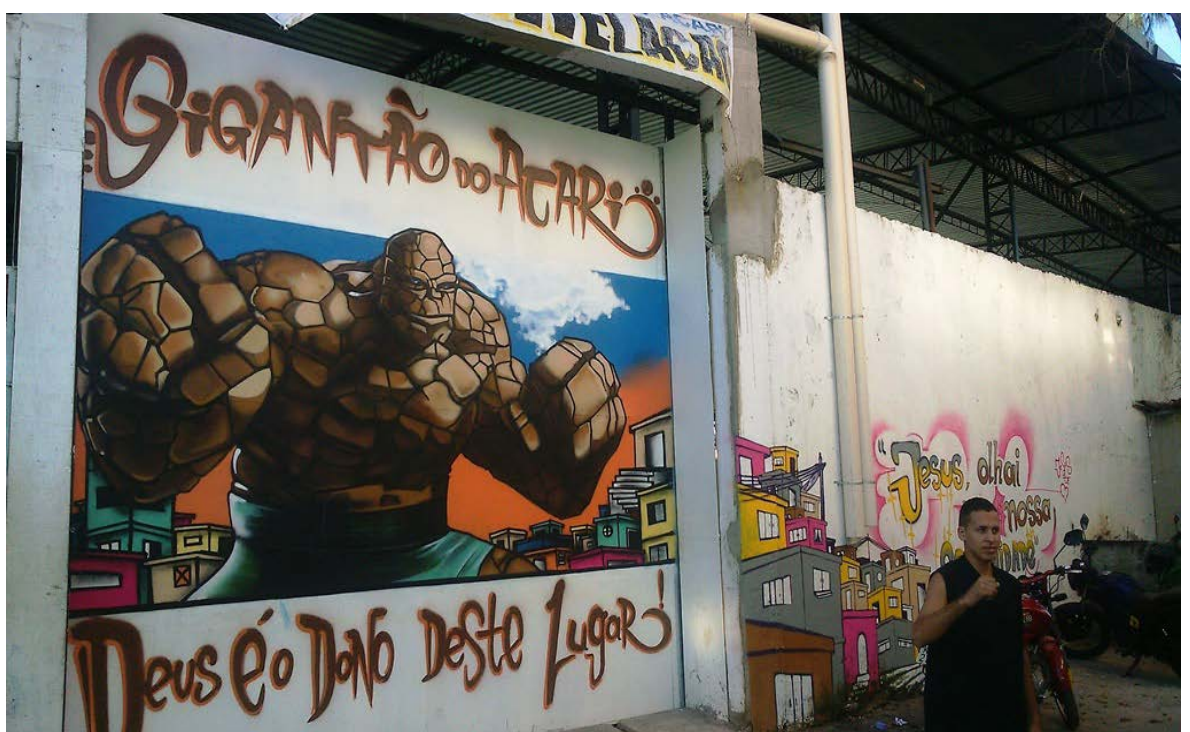

Imagem 7. Grafite no portão e no muro Quadra de Acari. No muro à direita está escrito "Jesus olhai por nossa comunidade". Foto: Christina Vital. Ano 2015.

A Quadra de Areia é identificada como um espaço privilegiado (mas não exclusivo) de sociabilidade de traficantes entre eles e com outros moradores de Acari (Alvito, 2001). Ali ocorriam jogos de futebol, jogos de cartas, bailes funk, alguns shows gospel financiados, segundo moradores, pelos próprios traficantes. $\mathrm{Na}$ quadra polivalente agora se realizam outros jogos. Uma nova estética se apresenta, mas a marca de "território de traficantes" permanece. O atual chefe do tráfico decorou o interior da quadra com grafites (encomendados de artistas cariocas) que remetem a ícones étnicos, da música e dos esportes.

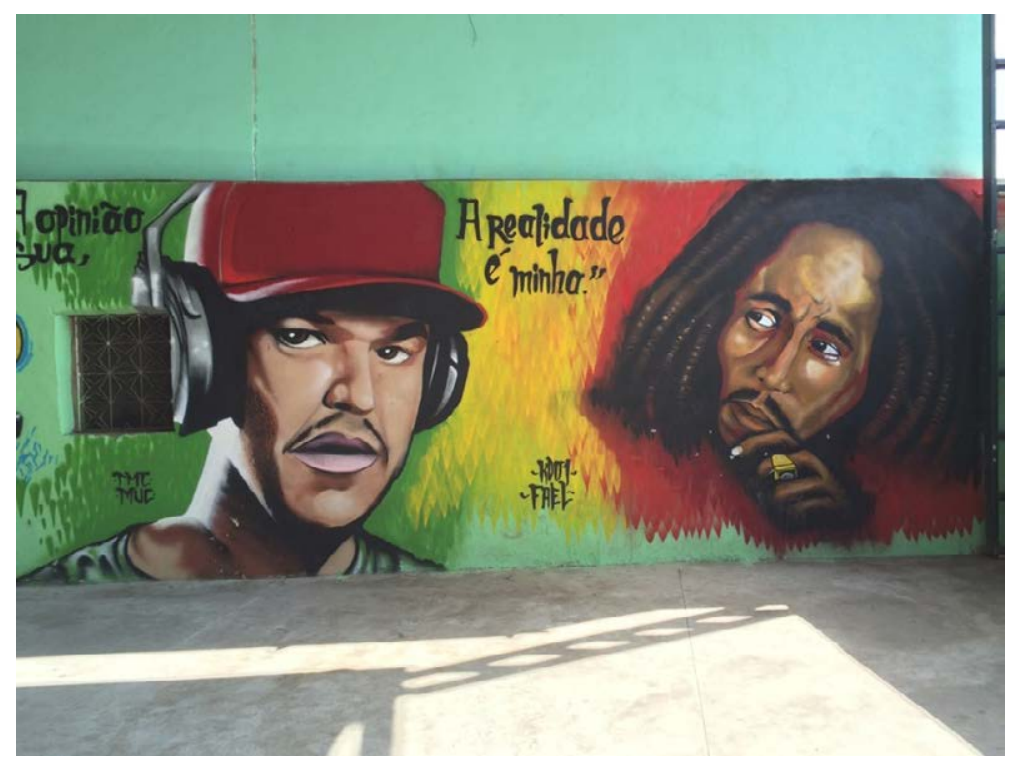

Imagem 8. Grafite no interior da Quadra de Acari. Entre os ícones do Hip Hop e do Reggae lê-se "A opinião é sua, a realidade é minha”. Imagem de Christina Vital. Ano 2015. 
No interior da quadra existe ainda um rato pintado em um mural de mais de 4 metros de altura. O rato se refere ao animal de estimação do traficante, hábito tão convencional entre os chefes do tráfico das décadas de 1980 e 1990, segundo noticiado em jornais da época e em livros de diferentes autores (Alvito, 2001; BARBOSA, 1997; LARANGEIRA, 2004).

Chama atenção que na parte externa da quadra os símbolos usados sejam cristãos, mobilizando uma estética jovem e uma gramática evangélica, considerando Jesus como parte desta gramática, como Droogers (1987) desenvolveu em seu artigo sobre a religião mínima brasileira. $\mathrm{O}$ autor argumentava que a hegemonia católica no Brasil se apresentava também pelo uso corrente do vocábulo Deus e do nome dos santos no espaço público. Isso se modificou com o crescimento de evangélicos no país. A partir de então, Jesus e outros termos passaram a ser mobilizados seja de modo jocoso em programas humorísticos para caracterizar "crentes" suburbanos, seja de modo coloquial na comunicação cotidiana de moradores de camadas médias e baixas residentes, principalmente, em bairros da Zona Norte, favelas e periferias cariocas e de outras cidades.

Exemplos desses termos que têm como referência a teologia da prosperidade e do domínio e/ou momentos rituais de igrejas pentecostais seriam: vitória, batalha, confirmação, guerra espiritual, provação, temer ao Senhor, tem que se dobrar, calor do Espírito Santo, posso tudo naquele que me fortalece, sou mais do que vencedor, em nome de Jesus, a palavra tem poder, o sangue de Jesus tem poder, alegria do Senhor é a nossa força, cura, unção, abençoado, benção, sapatinho de fogo, glória, aleluia, amém, tá amarrado, selado, vaso, servo, varão/varoa, obra, para a honra e para a glória, maligno, tremendo, Deus vai te usar tremendamente, Deus é contigo, manto, Paz do Senhor, entre outros. Imagens e palavras articuladas para o avivamento de sentimentos e identidades religiosas e ao mesmo tempo do crime nestes contextos.

Esses termos estão no cotidiano de moradores de favelas e periferias, seja como adesão ou como crítica, revelando dominação e disputa, a religião como prática e sentimentos que unem, mas também como dispositivo. Um meio de busca de proteção e de identificação entre moradores e traficantes, uma forma de comunicar também acordos morais e pertencimentos, relações e adesões, ainda que parciais. Na fala de um morador as especulações em torno desses usos gramaticais e estéticos emergem. Nos exercícios de limpeza moral de alguns entrevistados evangélicos, sobretudo mulheres, a vinculação religiosa de traficantes e de alguns outros moradores que não dariam "bom testemunho" eram sempre alvo de dúvida, especulações. 
“O povo que era ligado ao candomblé, que acreditava em imagens, deixou de acreditar. E voltaram mais pro lado evangélico, digamos. Não que todos acreditem. Muitos frequentam o culto, mas, assim, é... frequentam até mesmo pedindo proteção. Como na verdade eles iam aos centros de macumba e pediam proteção, fechavam o corpo, usavam guia... hoje em dia mudou. Hoje em dia eles vão pra igreja, pedem oração e andam com a Bíblia no bolso. É uma coisa, assim, até muito legal isso. Antes eles andavam com guia, com patuá e hoje em dia vão à igreja, pedem oração, andam com aqueles folhetinhos no bolso, andam com Bíblia no bolso, aquelas Bíblia Novo Testamento e Salmos, mas, tão aí no mundo. Assim, eu não sei qual a segurança que eles têm. Não sei se é a mesma visão que eles tinham, a guia protegia eles e a Bíblia vai proteger também... não sei qual é a visão deles". (Entrevista realizada com morador de Acari - Favela de Acari - Janeiro de 2009)".

Tornou-se um modo de expressão comum, um código que comunica lugares sociais, às vezes jocosidade, mas, de todo modo, expressivo de uma base social que se não está institucionalmente vinculada às igrejas que professam a fé cristã em estilo pentecostal, costuma ter neste universo religioso uma referência com a qual têm que lidar seja para experimentar o conforto de estar entre os iguais, seja para compreender e refutar. Os dados empíricos coletados em campo apresentam um desafio a mais para os que pretendem analisar a vida social em periferias, isto é, para investigar dinâmicas políticas, econômicas ou do crime é preciso considerar os códigos e referenciais morais pentecostais e de outras religiões ainda presentes, mesmo que diminutamente, nesses territórios.

As pinturas no interior da quadra e a pintura no portão dela são emblemáticas desse movimento de ocultação e revelação de crenças e valores, da relação dos traficantes com a "comunidade imaginada" evangélica ao seu redor. Se dentro as pinturas são "mundanas", no exterior são em conformidade com o que a "comunidade imaginada" se identifica. Podemos pensar dentro e fora da quadra como regiões morais distintas ${ }^{19}$ cuja gramática e a estética são marcadores de distinção: de fora a relação com a sociedade envolvente e que espera um comportamento e que

19 Regiões morais, segundo Goffman, seriam compostas por aquelas de fachada e de fundo. Ambas teriam condicionantes e corresponderiam a situações sociais que demandam diferentes posicionamentos/comportamentos dos atores. Na região de fachada experimenta-se um grau maior de constrangimento público, de exposição, o que demanda atuar correspondendo a expectativas sociais a partir de um processo de manipulação das impressões. Na região moral de fundo os sujeitos continuam atuando uns diante dos outros, contudo, de um modo menos controlado publicamente, o que possibilita a sensação de se "ser como se é". 
se apresenta a partir de determinadas imagens, por dentro a revelação de um self na interseção com outros. A despeito da posse de armas tornar desigual qualquer tipo de negociação direta entre moradores e traficantes (Machado da Silva 2008), o comércio de drogas local depende não só controle da população pelo medo, mas também de laços de afetividade, reciprocidade que sustentem uma convivência pacífica entre as partes. Nesse sentido, ainda que o chefe do tráfico local não seja evangélico, na área comum da favela ele financia grafites cristãos. No interior da Quadra, território inegociável de seu controle, os grafites têm outras formas e mensagens estéticas e textuais próprias.

\section{CONSIDERAÇ̃̃ES FINAIS}

As dinâmicas sociais possíveis através dos trabalhos de campo em favelas e da bibliografia especializada (EsperançA, 2012; GALdEAno, 2014; MaChado, 2013a, 2013b; Mafra, 1998, 2002; Marques, 2015; Novaes, 2003; Souza, 2017; Teixeira, 2011, 2013), nos fornecem elementos para pensar sobre a conformação de uma cultura pentecostal em periferia. Esse modo pentecostalizado de expressão é englobante e hibridiza com outras referências religiosas precedentes deixando evidentes disputas por hegemonia cultural, ou seja, simbólica, estética, gramatical, política, moral. Não exclui, mas atualiza moral e ritualmente. Vale-se da base cristã comum que já havia e das crenças igualmente difusas em entidades, espíritos, no mundo sobrenatural.

Sendo assim, o pentecostalismo existente se aproveita de um conjunto de referenciais morais e religiosos atualizando-os em seus próprios termos, como analisou Robbins (2004). Os pentecostais, por exemplo, não negam a força da mensagem católica, mas a julgam equivocada pelo que identificam como idolatria a santos e à Virgem Maria. Ao mesmo tempo, não negam a força de entidades e orixás da Umbanda e Candomblé, pelo contrário, a elas atribuem grande poder maligno, forte, mas demoníaco e que deveria, por isso, ser combatido. Assim, nas periferias, a gramática pentecostal e seus valores morais vão se transformando cada vez mais em códigos comuns a emergirem de distintas formas nos corpos, mentes e muros.

Esta "cultura pentecostal" que vem crescendo em periferias e favelas e se difundindo na sociedade, disputando a cultura secular nacional, representa, em parte, um desafio ao Brasil tradicional nos termos de Sanchis (1997). Por um lado, é disruptiva, é "solvente" de laços familiares, porque rompe com a coletividade pregressa. É predatória, extrativista, pois “extrai sistematicamente os membros das outras coletividades" (PIERUCCI, 2006, p. 112). 
Em favelas e periferias hoje, as redes pentecostais atuam reforçando sentidos de família, laços de amizade, parentesco e de vizinhança, produzindo segurança ontológica. Vão se apresentando como um estilo de vida ${ }^{20}$ fundamental no meio urbano disputado entre forças do bem e do mal. Ganham força na difusão, em tornar paulatinamente secular (comum a todos, indistintamente) aquilo que atualizou em suas doutrinas e rituais. Oferecem conforto espiritual e escuta especializada, já que é crescente o número de pastores, missionárias, diáconos, obreiros formados em psicologia e que oferecem escuta e meios de seus interlocutores "trabalharem suas emoções”, nos termos de Arlie Hochschild (1983). São elementos funcionais de seu crescimento e expansão, como chama atenção de modo crítico Birman (2012), mas que devem sempre ser lembrados nas análises porque produzem vivências, experiências e não se contrapõem a outras explicações que consideram aspectos mais teológicos e doutrinários, além de performáticos de seus líderes.

Os conflitos eclodem e se diluem rotineiramente e a bibliografia especializada tem coberto isso. No entanto, vale ressaltar que a presença de referências pentecostais na região moral da fachada (o muro da Quadra, por exemplo) e sua ocultação na região moral de fundo (parte interna da Quadra, por exemplo) não invalida sua consideração analítica como código comum. Pelo contrário, estar na região de fachada é indicativo não do que é “verdadeiro", mas do que é socialmente imposto, o que comunica positivamente em cada tempo.

Nesse sentido, o acompanhamento de um fio da história nos permite dizer que as bases do que Pierre Sanchis chamou na década de 1990 de uma "cultura popular urbana tradicional" e que envolveriam o catolicismo e religiões de matriz afro-brasileira mudaram drasticamente. Hoje, as bases dessa cultura pentecostal em periferia atualizam crenças existentes em moldes pentecostais produzindo novas sociabilidades, circulações urbanas, movimentos sociais urbanos com uma juventude evangélica engajada na luta por uma sociedade mais justa e igualitária, com mais respeito aos direitos humanos e redução do racismo, mães cujos filhos foram vítimas da violência policial e da "violência urbana" ganham força na leitura de passagens bíblicas para suas ações políticas na sociedade, novas estéticas, músicas, gramáticas (CARvalho, 2017; Novaes, 1990; Sant’Ana, 2017; Souza, 2017), como podemos ver no documentário Auto de Resistência, de Natasha Neri e Lula Carvalho (2018).

20 Em Wirth (1979) há uma discussão de referência para os estudos urbanos no que tange, principalmente, à noção de estilo de vida. Tal noção está na base de formulações potentes dos estudos urbanos no Brasil como as de Magnani (2012) sobre os pedaços e manchas nas cidades. 
O crescimento no número de evangélicos na base social vem mudando a política institucional, fazendo com que eles assumam importância cada vez maior nos pleitos desde a redemocratização e, acentuadamente, desde 2010 até os dias atuais (Vital da Cunha et al, 2017, Vital da Cunha; Evangelista 2019, Mariano 2016). Agenciamentos políticos se organizam em relação à crescente base evangélica na sociedade. Se a classe C corresponde a mais de 50\% do eleitorado nacional e os evangélicos estão majoritariamente nesta classe social, a mobilização de narrativas e estéticas evangélicas pelos candidatos pode ser em parte assim justificada. Nas eleições gerais de 2018, por exemplo, a maior parte dos candidatos vitoriosos mobilizou sentimentos de oposição, conflito, guerra de um suposto bem em relação a um suposto mal recorrendo, em muitos casos, diretamente a uma gramática da "batalha espiritual", escatológica, assim como a uma retórica da perda ${ }^{21}$.

O uso estratégico destes recursos estéticos e discursivos foi influenciado grandemente por líderes evangélicos que se apresentam como verdadeiros defensores da "palavra", inspirados nas eleições norte americanas de 2016 (CunHA, 2020). Para além das estratégias políticas baseadas em dados e estatísticas, o crescimento da base pentecostal no Brasil (seja institucional ou em termos difusos, "culturais") informa sobre uma sensibilização para um determinado referencial moral. As campanhas diagnosticam e vão se organizando em termos dessas expectativas, em termos desses referenciais que tocam mentes e corações de um grupo crescente e heterogêneo.

Deste modo, poderia dizer que os traços de uma cultura pentecostal em periferias hoje seriam, de modo muito sucinto, marcados pela: 1) Valorização do empreendedorismo e da disciplina para o sucesso como resultado de diferentes influências dentre as quais destacaria a Teologia da Prosperidade ${ }^{22}$ e a Confissão Positiva. Através delas são trabalhados sentimentos de confiança no presente e no

21 "Uma retórica da perda se anunciava. Esta, tal como iniciamos sua formulação no livro Religiãoe Política: medos sociais, extremismo religiosos e as eleições 2014, pode ser considerada como um tática discursiva articulada por diferentes lideranças sociais e políticas (dentre elas, religiosas) baseada em um imperativo: o retorno da ordem, da previsibilidade, da segurança, da unidade, da autoridade. É um discurso que se contrapõe a mudanças sociais experimentadas socialmente no mundo a partir dos anos 1990 e, no Brasil, especialmente a partir de meados dos anos 2000. A insegurança moral e até ontológica produzida por mudanças em paradigmas sobre corpo e sexualidade, somado ao aumento da violência armada no campo e na cidade produziu em um contingente significativo da população um desejo de retorno a um status quo ante no qual não se sentia tantas ameaças físicas, morais e patrimoniais" (VITAL DA CUNHA, 2020, p. 134).

22 A Teologia da Prosperidade ganhou expressão no Brasil a partir da década de 1980, sobretudo em denominações surgidas neste período, embora todo o campo evangélico e mesmo católico carismático tenha sido por ela afetado. Esta teologia se baseia em uma interpretação de alguns livros bíblicos, com destaque para o livro de Malaquias. Como nos lembra Teixeira (2016), a prosperidade não está relacionada exclusivamente ao sucesso financeiro, mas à harmonia entre as diversas dimensões da vida dos fieis como estudos, saúde, família, conjugalidade etc. 
futuro, empoderamento, performances corporais. Além do incentivo à abertura de um negócio próprio, são valorizados o engajamento em projetos culturais, artísticos e esportivos (muitas vezes realizados por instituições religiosas) anunciados como potentes inculcadores desta "disciplina para o sucesso"; 2) Noção de que o esforço pessoal produz vitórias, o que fornece as bases do item anterior. É importante destacar que, em contexto social de vulnerabilidade, nos quais o Estado oferece precariamente seus serviços, o "contar consigo mesmo" e com redes mais ou menos orgânicas de vizinhança e parentesco sempre foram recursos para sobrevivência. Contudo, observa-se uma ênfase em esforços individuais, embora essas redes continuem proporcionando apoio, quando disponíveis; 3) Uma valorização moral da família nuclear e de papeis de gênero definidos entre homem e mulher - uma forma de exemplaridade de gênero cristã performada cotidianamente (MoRAEs, 2014; Dullo, 2011), 4) Do ponto de vista religioso, uma diminuição no que Sanchis chamou de "porosidade das identidades que permitia a cada um participar ao mesmo tempo de definições institucionais múltiplas" (SANCHIS, 1997, p. 124); 5) Amplo uso de metáforas e analogias que remetem à guerra (entre bem e o mal), disputa (das almas por forças antagônicas), atribulação (luta cotidiana dos indivíduos por sobrevivência material e espiritual), todas formas inspiradas em uma Teologia do Domínio que marca as doutrinas e ritualísticas de igrejas pentecostais e neopentecostais hoje.

Essa cultura pentecostal em periferia é resultante de muitos processos endógenos e exógenos às igrejas e à própria sociabilidade local. Seu avanço e o estabelecimento de que é forjado em meio a conflitos, resistências, adesões apaixonadas e constrangimentos. Não é inconteste, como nada o é em termos sociais, sendo atualizada constantemente.

\section{REFERÊNCIAS BIBLIOGRÁFICAS}

Almeida, Ronaldo. "A expansão Pentecostal: circulação e flexibilidade”. In: Teixeira, Faustino; Menezes, Renata (eds.). As religiões no Brasil: continuidades e rupturas. Petrópolis, Vozes, 2006, p. 111-122.

Alvito, Marcos. As cores de Acari: uma favela carioca. Rio de Janeiro, FGV, 2001.

Anderson, Benedict. Comunidades imaginadas. Reflexões sobre a origem e a difusão do nacionalismo. São Paulo, Companhia das Letras, 2008.

AsaD, Talal. Genealogies of religion: Discipline and Reasons of Power in Christianity and Islam, Baltimore, The Johns Hopkins University Press, 1993.

BARBOSA, Antonio Rafael. Um abraço para todos os amigos: algumas considerações sobre o tráfico de drogas no Rio de Janeiro. 1. ed. Niterói, EDUFF, 1997. 
BARBosa, Lívia. O Jeitinho Brasileiro ou a Arte de ser mais Igual que os Outros. 6. ed. Rio de janeiro, Campus, 1992.

Berger, Peter. $O$ dossel sagrado. São Paulo, Paulus, 2004.

Birman, Patrícia. Cultos de possessão e Pentecostalismo no Brasil: passagens. Religião e Sociedade, vol. 17, pp. 90-109, 1996.

Birman, Patrícia. O poder da fé, o milagre do poder: mediadores evangélicos e deslocamento de fronteiras sociais. Horizontes Antropológicos, Porto Alegre, 2012.

Birman, Patricia; Machado, Carly. A violência dos justos: evangélicos, mídia e periferias da metrópole. Revista Brasileira de Ciências Sociais. vol.27, n.80, pp.55-69, 2012.

BRANDÃo, Carlos. O divino, o santo e a senhora. Rio de Janeiro, Funarte, 1978.

CAmpos, Roberta Bivar; MaUricio Junior, Cleonardo. As formas elementares da liderança carismática. Mana. Estudos de Antropologia Social, vol. 19, n. 02, pp. 249-276, 2013.

CARvalHo, José Jorge. "Características do fenômeno religioso na sociedade contemporânea”. In: Bingemer, Maria Clara Lucchetti. (ed.), O impacto da modernidade sobre a religião. São Paulo, Loyola, 1992, p. 133-64.

Carvalho, Olívia Bandeira de Melo. O mundo da música gospel entre o sagrado e o secular: disputas e negociações em torno da identidade evangélica. Tese (Doutorado em Sociologia e Antropologia), Universidade Federal do Rio de Janeiro, Rio de Janeiro, 2017.

Cunha, Magali. Fundamentalismos, crise da democracia e ameaça aos direitos humanos na América do Sul: tendências e desafios para a ação. Salvador, Koinonia. 2020.

DA MatTa, Roberto. A casa e a rua. Rio de Janeiro, Guanabara, 1991.

DAS, Veena. Life and words: violence and the descent into the ordinary. Berkeley, University of California Press, 2007.

Droogers, André. A religiosidade mínima brasileira. Religião e Sociedade, n. 14, vol 02, pp. $62-87,1987$.

Dullo, Eduardo. Uma pedagogia da exemplaridade: a dádiva cristã como gratuidade. Religião \& Sociedade, vol. 31, n. 2, pp. 105-129, 2011.

ELIADE, Mircea. O sagrado e o profano: a essência da religião. São Paulo, Martins Fontes, 1992.

ESPERANÇA, Vinícius. Poder divino e poder armado no Batan. Comunicações do ISER, vol. 67, pp. 89-105, 2012.

Feltran, Gabriel Sanctis. Fronteiras de tensão: política e violência nas periferias de São Paulo. 1. ed. São Paulo, Editora Unesp/CEM, 2011.

FELtRAn, Gabriel Sanctis. Sobre anjos e irmãos: cinquenta anos de expressão política do crime numa tradição musical das periferias. Revista do Instituto de Estudos Brasileiros, v. 56, no 1, p. 43-72, 2013. 
Fernandes, Rubem C.; Sanchis, Pierre; Velho, Otávio G.; Piquet, Leandro; Mariz, Cecília; MAFRA, Clara. Novo nascimento: os evangélicos em casa, na política e na igreja. Rio de Janeiro, Mauad, 1988.

Freston, Paul. Uma breve história do Pentecostalismo brasileiro: a Assembléia de Deus. Religião e Sociedade, vol. 16, no 3, pp. 104-129, 1994.

Galdeano, Ana Paula. Salmo 127, versículo 1: ativismo religioso e ordenamentos da segurança nas periferias de São Paulo. Religião e Sociedade, vol. 34, no 1, pp. 38-6o, 2014.

Giumbelli, Emerson, "A presença do religioso no espaço público: modalidades no Brasil”. Religião e Sociedade, vol. 28, no 2, pp. 80-101,2008.

Giumbelli, Emerson. "Crucifixos invisíveis: polêmicas recentes no Brasil sobre símbolos religiosos em recintos estatais”. Anuário Antropológico, vol. 10, no 1, pp. 77-105. 2010. Giumbelli, Emerson. “Cultura Pública: evangélicos y su presencia en la sociedad brasileña”. Sociedad y Religión, vol. 23, pp. 13-43, 2013.

Gofman, Erving. A representação do eu na vida cotidiana. Rio de Janeiro, Zahar, 1995. Gomes, Edlaine de Campos. Doce de Cosme e Damião: dar, receber, ou não? In: Gomes, Edlaine de Campos. Dinâmicas Contemporâneas do Fenômeno Religioso na Sociedade Brasileira. Aparecida, Idéias e Letras, 2009, p. 169-185.

JАСов, César Romero. Território, cidade e religião no Brasil. Religião e Sociedade, vol. 24, no 2, pp. 126-151, 2004.

LARANGEIRA, Emir. Cavalos corredores: a verdadeira história. Rio de Janeiro, Editora Beto Brito, 2004.

LATOUR, Bruno. 'Não congelarás a imagem', ou: como não desentender o debate ciênciareligião”. Mana. Estudos de Antropologia Social, vol.10, no 2, p. 349-376, 2004.

LoPEs, Natânia. Crime como religião. Trabalho publicado nos anais da $28^{\mathrm{a}}$ Reunião Brasileira de Antropologia, 2012, São Paulo.

Machado Da Silva, Luiz Antonio. Vida sob cerco: violência e rotinas nas favelas do Rio de Janeiro. Rio de Janeiro, FAPERJ/Nova Fronteira, 2008.

MaChADO, Carly. Resgatando vidas, restituindo cidadania e promovendo a inclusão social: projetos religiosos, midiáticos e políticos de uma Assembleia de Deus da Baixada Fluminense na criação de circuitos das e nas periferias cariocas e fluminenses. Comunicação apresentada na 10a Reunião de Antropologia do Mercosul, Buenos Aires, Argentina, 2013a.

MACHADo, Carly., 'É muita mistura': projetos religiosos, políticos, sociais, midiáticos, de saúde e segurança pública nas periferias do Rio de Janeiro. Religião \& Sociedade. vol.33, n.2, pp.13-36. 2013b. 
MAFRA, Clara.), "Drogas e símbolos: redes de solidariedade em contextos de violência”. In: Zaluar, Alba; Alvito, Marcos (orgs.), Um século de favela. Rio de Janeiro, Editora Fundação Getúlio Vargas, pp. 277-298, 1998.

Mafra, Clara. A 'arma da cultura' e os 'universalismos parciais'. Mana. Estudos de Antropologia Social, vol. 17, no 3, pp. 607-624, 2011.

Mafra, Clara; Paula, Robson de. O espírito da simplicidade: a cosmologia da batalha espiritual e as concepções de corpo e pessoa entre policiais pentecostais cariocas. Religião e Sociedade, vol. 22, no 1, pp. 57-76, 2002.

MaGgie, Yvonne. (1992), Medo e feitiço: relações entre magia e poder no Brasil. Rio de Janeiro, Arquivo Nacional, 1992.

Magnani, José Guilherme Cantor. "Religião e metrópole”. In: Mafra, Clara; Almeida, Ronaldo (orgs.). Religiões e cidades: Rio de Janeiro e São Paulo. São Paulo, Editora Terceiro Nome, 2009, p. 19-28.

Magnani, José Guilherme Cantor. Da periferia ao centro: trajetórias de pesquisa em antropologia urbana. São Paulo, Editora Terceiro Nome, 2012.

Mariano, Ricardo. Neopentecostais: sociologia do novo Pentecostalismo no Brasil. São Paulo, Loyola, 1999.

Mariano, Ricardo. Expansão e ativismo político de grupos evangélicos conservadores., Civitas, Porto Alegre, vol. 16, no. 4, p. 710-728, 2016.

Mariz, Cecília. A teologia da guerra espiritual: uma revisão da literatura sócio antropológica. Revista Brasileira de Informação Bibliográfica em Ciências Sociais, vol. 47, pp. 33-48, 1999.

Marques, Adalton. Crime e proceder: um experimento antropológico. 1. ed. São Paulo, Alameda, 2014.

Marques, Vagner Aparecido. Fé \& Crime: evangélicos e PCC nas periferias de São Paulo. São Paulo, Fonte Editorial, 2015.

MAUSs, Marcel; HUBERT, Henri. “Esboço de uma teoria geral da magia”. In: Mauss, Marcel. Sociologia e Antropologia. São Paulo, Cosac \& Naify, 2003, p. 47-181.

Menezes, Renata de Castro. "Doces santos: sobre os saquinhos de Cosme e Damião". In Gomes, Edlaine; Oliveira, Paola Lins de (orgs.), Olhares sobre o patrimônio religioso. 1ed. Rio de Janeiro, Mar de Ideias, 2016, pp. 57-87.

MODESTO, Ana Lucia. Experiência, conceito e efeitos sociais: estética e novas perspectivas para a sociologia. Trabalho apresentado na Mesa Redonda "A bela esquina ou é a Estética um duplo das Ciências Sociais?” no $41^{\circ}$. Encontro Anual da ANPOCS, Caxambu, 2017.

Montero, Paula. Religião, pluralismo e esfera pública no Brasil. Novos Estudos CEBRAP, no. 74, 2006. 
Montero, Paula. Multiculturalismo, identidades discursivas e espaço público. Revista Sociologia \& Antropologia, vol. 4, no, 2, pp. 81-101, 2012 a.

Montero, Paula. Controvérsias religiosas e esfera pública: repensando as religiões como discurso. Religião e Sociedade, vol. 1, no 32, 2012b.

Montero, Paula. 'Religiões Públicas' ou Religiões na esfera Pública? Para uma crítica ao conceito de campo Religioso de Pierre Bourdieu. Religião e Sociedade, vol. 36, no 1, pp. 128-150, 2016.

Montero, Paula. Religião cívica, religião civil, religião pública: continuidades e descontinuidades. Debates do NER, ano 19, no. 33, pp. 15-39, 2018;

Moreira, Alberto da Silva. A religião sob o domínio da estética. Horizonte, vol. 13, no. 37, p. 379-405, 2015.

Musil, Robert. Monuments. Posthumous papers of a living author. New York, Archipelago Books. 2006 [1946].

Novaes, Regina Celia Reyes. Ouvir para crer: os Racionais e a fé na palavra. Religião \& Sociedade, vol.20, no 1, pp. 55-64, 1990.

Novaes, Regina Celia Reyes., De corpo e alma. Catolicismo, classes sociais e conflitos no campo. Rio de Janeiro, Ed. Graphia, 1997.

NovaEs, Regina Celia Reyes. "Errantes do novo milênio: salmos e versículos bíblicos no espaço público”. In: Birman, Patricia; Leite, Márcia Pereira (orgs.). Religião e espaço público. São Paulo, Attar, 2003, p. 25-40.

Novaes, Regina Celia Reyes. Pierre Sanchis: razão e sensibilidade, Homenagem ao Professor Pierre Sanchis (16/12/1928 - 7/5/2018), ISER [online], mai. 2018. Disponível em $<$ http://www.iser.org.br/site/2018/05/29/homenagem-ao-professor-pierre-sanchis16121928-75218-por-regina-novaes/>, acesso em agosto de 2018.

OosterbaAn, Martijn. Spiritual Attunement: Pentecostal Radio in the Soundscape of a Favela in Rio de Janeiro. Social Text 96. Vol. 26, No. 3, pp. 123-145, 2008.

ORo, Ari Pedro. Messianismo, milenarismo e religiosidade popular. Revista Brasileira de Ciências Sociais, vol. 2, no 1, pp. 73-84, 1988.

Oro, Ari Pedro; AlvEs, Daniel. Renovação Carismática Católica: movimento de superação da oposição entre catolicismo e pentecostalismo?. Religião \& Sociedade vol. 3, pp. 122-144, 2003.

PaIvA, Geraldo José de. Experiência religiosa e experiência estética em artistas plásticos: perspectivas da psicologia da religião. Psicologia: Reflexão e Crítica, vol.17, no 2, pp. 223-232, 2004.

PIERUCCI, Antonio Flávio. Pentecostal networks and the spirit of globalization: on the social productivity of ritual forms. Social Analysis, vol. 53, no 1, pp. 55-66, 2009. 
Pierucci, Antonio Flávio. (2006). A religião como solvente: uma aula. Novos estudos CEBRAP, no 75, pp. 111-127, 2006.

RANciÈre, Jacques. A partilha do sensível: estética e política. São Paulo, Editora 34, 2005. Robbinss, Joel. The globalization of Pentecostal and charismatic Christianity. Annual Review of Anthropology, no. 33, pp. 117-143, 2004.

RochA, Gilmar. Roupa Animada - persona e performance na jornada dos Santos Reis. Cronos: R. Pós-Grad. Ci. Soc., no 15, vol. 2, pp. 8-34, 2014.

SANChIS, Pierre. Uma identidade católica? Comunicações do Iser. no. 22, pp. 5-16, 1986. SANchis, Pierre. O repto pentecostal à cultura católico-brasileira. Revista de Antropologia (USP), no. 37, pp. 145-182, 1994.

SAnchis, Pierre. Pentecostalismo e cultura brasileira. Revista Religião e Sociedade, vol. 18, no 2, pp. 123-126, 1997a.

SAnchis, Pierre. As religiões dos brasileiros. Horizonte. Vol. 1, no 2, pp. 28-43, $1997 \mathrm{~b}$.

SANCHIS, Pierre. Tributo ao Professor Emérito Joseph François Pierre Sanchis. Programa de Pós-Graduação em Antropologia da Universidade Federal de Minas Gerais, 2018. https://www.fafich.ufmg.br/ppgan/?s=homenagem+pierre+sanchis

SANSI, Roger. Fetiches e monumentos. Arte pública, iconoclastia e agência no caso dos 'orixás' do Dique do Tororó. Religião e Sociedade, vol. 25, no 2, pp. 62-81, 2005.

SAnT'Ana, Raquel. A nação cujo Deus é o Senhor: a imaginação de uma coletividade "evangélica” a partir da Marcha para Jesus. Tese (Doutorado em Antropologia). Universidade Federal do Rio de Janeiro, Rio de Janeiro, 2017.

ScHWARCZ, Lilia Moritz. Lendo e agenciando imagens: o rei, a natureza e seus belos naturais. Sociologia e antropologia, vol 4, no 2, pp. 391-431, 2014.

SiLva, Vagner Gonçalves da. (2006), “Continuidades e Rupturas entre neopentecostalismo e religiões afro-brasileiras”. In: As Religiões no Brasil: continuidades e rupturas. Teixeira, Faustino; Menezes, Renata (orgs.). Petrópolis, RJ: Vozes, 2006. pp. 207-228. SILvA, Vagner Gonçalves da. "Arte religiosa afro-brasileira: as múltiplas estéticas da devoção brasileira”. Debates do Ner. Vol. 9, no 13, pp. 97-113, 2008.

Simmel, Georg. O conceito e a tragédia da cultura. Crítica Cultural - Critic. vol. 9, no. 1, pp. 145-162, 2014.

Simmel, Georg. Questões fundamentais da sociologia: indivíduo e sociedade. Rio de Janeiro, Zahar, 2006 [1908].

SouZA, Patrícia Lânes Araújo. Entre becos e ONGs: etnografia sobre engajamento militante, favela e juventude. Tese (Doutorado em Antropologia). Universidade Federal Fluminense, Niterói, 2017.

Steil, Carlos Alberto. "Catolicismo e cultura". In: VAlla, Victor Vincent (org.), Religião e cultura popular. Rio de Janeiro, DP\&A Editora. vol. 17, 2001, pp. 9-40. 
Steil, Carlos Alberto. Fidelidades criativas: Ciência, mística e amizade na trajetória de Pierre Sanchis. Revista Religião e Sociedade, vol. 38, n. 2, maio-agosto 2018.

Taussig, Michael. Defacement: Public secrecy and the labor of the negative. Stanford, University Press, 1999.

TAYLOR, Charles. Uma era secular. Porto Alegre, Unisinos, 2010.

Teixeira, Cesar Pinheiro. O pentecostalismo em contextos de violência: uma etnografia da relação entre pentecostais e traficantes em Magé. Ciencias Sociales y Religión v. 10, pp. 181-205, 2008.

Teixeira, Cesar Pinheiro. A construção social do 'ex-bandido': um estudo sobre sujeição criminal e Pentecostalismo. Rio de Janeiro, 7Letras, 2011.

Teixeira, Cesar Pinheiro. A teia do bandido: um estudo sociológico sobre bandidos, policiais, evangélicos e agentes sociais. Tese (Doutorado em Sociologia e Antropologia). Universidade Federal do Rio de Janeiro, Rio de Janeiro, 2013.

TEIXEIRA, Jacqueline Moraes. Mídia e performances de gênero na Igreja Universal: o desafio Godllywood. Religião \& Sociedade, vol 34, no 2, 2014.

Teixeira, Jacqueline Moraes. A mulher universal: corpo, gênero e pedagogia da prosperidade. Rio de Janeiro, Mar de Ideias - Navegação Cultural, 2016.

Türcke, Christopf. Sociedade excitada: filosofia da sensação. Campinas, Ed. da Unicamp, 2010.

Vital Da Cunha, Christina. “Traficantes evangélicos”: novas formas de experimentação do sagrado em favelas cariocas. Plural - Revista de ciências sociais, v. 15, p. 13-46, 2008. Disponível em: https://www.revistas.usp.br/plural/article/view/75226. Acesso em: 29 maio. 2021.

Vital Da Cunha, Christina. Religião e criminalidade: traficantes e evangélicos entre os anos 1980 e 2000 nas favelas cariocas. Revista Religião e Sociedade, vol.34, no. 1, pp. 61-93, 2014.

Vital Da Cunha, Christina. Oração de traficante: uma etnografia. Rio de Janeiro, Editora Garamond/ FAPERJ, 2015.

VITAL DA CunHA, Christina. 'Televisão para salvar': Religião, mídia e democracia no Brasil Contemporâneo". Antropolítica. vol. 42, no. 1, pp. 20-48, 2017.

Vital Da Cunha, Christina. Retórica da Perda nas eleições presidenciais brasileiras em 2018: religião, medos sociais e tradição em foco. Revista Plural: Antropologías desde América Latina y el Caribe. Año 3, No 6. p. 123-149, 2020.

Vital Da Cunha, Christina; LOPES, Paulo Victor; LUI, Janayna. Religião e Política: medos sociais, extremismo religiosos e as eleições 2014. Rio de Janeiro, ISER, Fundação Heinrich Boll, 2017. 
Vital Da Cunha, Christina; Evangelista, Ana Carolina. Estratégias eleitorais em 2018: o caso das candidaturas evangélicas ao legislativo. Sur. Revista internacional de direitos humanos. vol. 29, pp. 87-100, 2019.

Weber, Max., Ensaios de Sociologia. Rio de Janeiro, Guanabara, 1982.

Wirth, Louis. (1979), “O urbanismo como modo de vida”. In: Velho, Otávio (org.). O fenômeno urbano. Rio de Janeiro, Jorge Zahar. Pp. 6-13.

ZAMORA, José A. Intimidad, Religión y Espetáculo, Caminhos, vol. 12, no. 2, p. 279-311, 2014.

\section{FILMOGRAFIA}

Auto DE RESISTÊNCIA. Direção de Natasha Neri e Lula Carvalho. Rio de Janeiro. 2018. (104 min.). 